\title{
ANALISIS FAKTOR-FAKTOR YANG MEMPENGARUHI KINERJA DRIVER GRAB-BIKE KABUPATEN BANJARNEGARA
}

\author{
Umi Wahidatul Lailiyah \\ Sekolah Tinggi Ilmu Manajemen YKPN Yogyakarta \\ Email : lelyfelishato@gmail.com \\ Tri Harsini Wahyuningsih \\ Sekolah Tinggi Ilmu Manajemen YKPN Yogyakarta \\ Email : triharsiniw@gmail.com
}

\begin{abstract}
ABSTRAK
Penelitian ini bertujuan untuk mengetahui pengaruh motivasi, insentif, dan kepuasan kerja terhadap kinerja driver Grab-Bike pada Grab Indonesia Wilayah Kabupaten Banjarnegara. Responden sebanyak 200 orang merupakan driver Grab-bike yang sudah bekerja minimal 6 bulan. Dari keseluruhan responden tersebut, $96 \%$ pria, $53 \%$ berusia diantara $20-30$ tahun, dan $58 \%$ berpendidikan SMA/K. Sampel diambil dengan teknik non probability sampling menggunakan metode purposive sampling, yaitu driver yang telah memiliki masa kerja minimal 6 bulan, karena bila kurang dari itu dimungkinkan belum bisa mengukur kinerjanya. Pengumpulan data dilakukan dengan menggunakan kuesioner. Setelah dilakukan uji instrumen, uji asumsi dasar, dan uji asumsi klasik maka diketahui bahwa semua variabel/item pernyataan diketahui dapat digunakan untuk penelitian. Berdasarkan hasil uji $t$ dan uji regresi linier berganda ditemukan bahwa motivasi dan kepuasa kerja berpengaruh positif dan signifikan terhadap kinerja driver, sedangkan insentif tidak berpengaruh terhadap kinerja driver Grab-bike yang bekerja di wilayah Kabupaten Banjarnegara.
\end{abstract}

Kata kunci: motivasi, insentif, kepuasan kerja, kinerja driver

\begin{abstract}
This study aims to determine the effect of motivation, incentives, and job satisfaction on the performance of the Grab-Bike driver on the Indonesian Grab in the Banjarnegara Regency Region. 200 respondents are Grab-bike drivers who have worked for at least 6 months. Of the total respondents, 96\% were men, 53\% were between 20-30 years old, and 58\% had high school education. Samples were taken by non probability sampling techniques using purposive sampling method, namely drivers who have had a minimum work period of 6 months, because if it is less than that it is possible not to be able to measure its performance. Data collection is done using a questionnaire. After testing the instrument, testing the basic assumptions, and testing the classical assumptions, it is known that all variables/item statements are known to be used for research. Based on the results of the t test and multiple linear regression tests, it was found that motivation and work authority had a positive and significant effect on driver performance, while the incentives did not affect the performance of the Grab-bike driver working in the Banjarnegara Regency area.
\end{abstract}

Keywords: motivation, incentives, job satisfaction, driver performance

\section{PENDAHULUAN}

Transportasi berbasis online saat ini merupakan hal yang tidak asing lagi bagi masyarakat Indonesia, baik di kota-kota besar maupun di kota-kota kecil. Kehadiran jasa transportasi ini disambut baik oleh masyarakat karena memudahkan orang untuk mendapatkan moda transportasi secara cepat, murah, aman, dan nyaman. Selain jasa pemindahan orang menggunakan motor (ojek) 
atau mobil (taxi), perusahaan berbasis online ini juga menyediakan jasa pemindahan/pengiriman barang, pembelian makanan, pembelian berbagai macam kebutuhan (belanja), dan berbagai macam jasa lainnya.

Perkembangan perusahaan semacam ini juga didukung oleh kemudahan masyarakat mendownload aplikasi yang tersedia pada smartphone yang dimilikinya. Ketersediaan smartphone di pasaran dengan berbagai jenis dan harga yang relatif murah menjadikan sebagian besar masyarakat memiliki alat komunikasi ini.

Sebagai salah satu perusahaan penyedia jasa, kinerja perusahaan ini sangat tergantung pada kinerja karyawan, dalam hal ini adalah driver yang melayani konsumen. Image perusahaan melekat erat dalam diri driver karena semua driver diwajibkan menggunakan jaket dan helm yang diperoleh dari perusahaan saat mereka mendaftarkan diri. Dengan demikian, semua driver harus berkomitmen untuk memberikan pelayanan terbaik kepada para konsumennya. Apabila ada salah satu driver yang mengecewakan konsumen maka yang terkena dampak negatif tidaklah driver itu saja melainkan langsung pada nama perusahaan. Hal ini dikarenakan dalam melakukan order, konsumen tidak dapat memilih drivernya, melainkan hanya dapat memilih jasa yang akan dibelinya, sedangkan driver ditentukan oleh sistem aplikasi yang telah diunduhnya.

Oleh karena kinerja perusahaan ditentukan oleh kinerja karyawan, maka perusahaan transportasi berbasis online harus memperhatikan faktor-faktor yang diperkirakan mempengaruhi kinerja driver. Setiyaningsih (2018) menemukan bahwa motivasi berpengaruh terhadap kinerja driver Go-Car PT Gojek Indonesia wilayah Yogyakarta dan Nugroho, dkk (2017) juga mendapatkan temuan yang sama dalam penelitiannya di Dinas Pertanian Kota Semarang. Selain motivasi, kinerja karyawan juga dipengaruhi oleh insentif berdasar penelitian Rompis dkk (2017) di PT Angkasa Pura I (Persero) Cabang Manado dan kepuasan kerja berdasar penelitian Hananto (2018) untuk driver Go-Jek di Jakarta Selatan. Secara konseptual, apabila karyawan memiliki motivasi tinggi dalam bekerja maka kinerjanya akan meningkat. Kinerja akan semakin meningkat bila perusahaan memberikan kompensasi dengan sistem insentif, karena insentif sebenarnya diberikan sebagai pembeda antara karyawan yang berkinerja tinggi dan karyawan yang berkinerja rendah. Demikian juga dengan kepuasan yang dirasakan karyawan dalam bekerja di perusahaannya pasti akan mempengaruhi kinerjanya.

Walaupun beberapa penelitian sebelumnya membuktikan bahwa motivasi, insentif, dan kepuasan kerja berpengaruh terhadap kinerja karyawan, namun ditemukan juga ternyata ketiga faktor tersebut tidak mempengaruhi kinerja karyawan pada perusahaan yang berbeda. Prihantini dkk (2017) mendapatkan hasil bahwa motivasi tidak berpengaruh terhadap kinerja karyawan PT BPR Kertha Arthamandiri Kepanjen Malang. Temuan tersebut sama dengan hasil penelitian Changgriawan (2017) di One Way Production. Insentif ditemukan tidak memberikan pengaruh terhadap kinerja pegawai dinas pertanian Kota Semarang (Nugroho dkk, 2017), sedangkan kepuasan kerja juga tidak mempengaruhi kinerja pegawai Puskesmas di Kalimantan Timur (Hidayati dan Rahmawati, 2015).

Belum banyaknya penelitian yang mengambil subyek driver GrabBike merupakan salah satu alasan dalam penelitian ini, selain karena adanya perbedaan hasil penelitian-penelitian sebelumnya seperti yang telah disampaikan di atas. Berdasarkan fenomena di atas maka penelitian ini bertujuan untuk: 1) menganalisis pengaruh motivasi terhadap kinerja driver Grabbike Kabupaten Banjarnegara, 2) menganalisis pengaruh insentif terhadap kinerja driver Grabbike Kabupaten Banjarnegara, 3) menganalisis pengaruh kepuasan kerja terhadap kinerja driver Grabbike Kabupaten Banjarnegara, dan 4) menganalisis pengaruh motivasi, insentif, dan kepuasan kerja secara simultan terhadap kinerja driver Grabbike Kabupaten Banjarnegara. Dengan demikian, diharapkan dapat memberikan manfaat bagi pihak GrabBike Indonesia untuk lebih memperhatikan faktor-faktor yang mempengaruhi kinerja drivernya, yang selama ini disebut sebagai mitra kerjanya. Kinerja driver akan mempengaruhi kinerja perusahaan secara keseluruhan.

\section{TINJAUAN PUSTAKA}

\section{Pengertian Sumber Daya Manusia}

Manajemen sumber daya manusia (MSDM) adalah proses untuk memperoleh, melatih, menilai, dan mengompensasi karyawan, dan untuk mengurus relasi tenaga kerja mereka, kesehatan dan keselamatan mereka, serta hal-hal yang berhubungan dengan keadilan (Dessler, 2015). Dalam 
perusahaan, MSDM mempunyai beberapa fungsi, yaitu: perencanaan, pengorganisasian, penyusunan staf, kepemimpinan, dan pengendalian. Secara keseluruhan fungsi-fungsi ini mewakili proses manajemen.

Kepemimpinan merupakan salah satu fungsi MSDM dalam perusahaan. Pada dasarnya, seorang pemimpin bertanggung jawab pada pencapaian tujuan perusahaan melalui karyawan yang menjadi bawahannya. Untuk itu, setiap pemimpin harus bisa mengarahkan dan memengaruhi bawahan supaya mengikuti semua perintahnya. Kedua proses tersebut tidak akan dapat berjalan lancar bila pemimpin tidak mampu memotivasi bawahannya dengan baik.

\section{Motivasi}

Motivasi merupakan sesuatu yang mendorong seseorang bertindak atau berperilaku tertentu (Hanafi, 2011). Motivasi membuat seseorang memulai, melaksanakan, dan mempertahankan kegiatan tertentu. Dengan demikian, motivasi dapat mendorong orang lain mengerjakan keinginan manajer agar tujuan organisasi tercapai. Untuk memahami konsep motivasi, perlu diketahui adanya beberapa teori motivasi yang disampaikan oleh beberapa ahli.

1. Teori Hirarkis Kebutuhan Maslow

Abraham Maslow (dalam Hanafi, 2011) mengemukakan hirarkis lima kebutuhan manusia, yaitu:

a. Fisiologis : kebutuhan akan udara, makan, minum, tempat tinggal, dan seks.

b. Keamanan: kebutuhan akan keamanan dan bebas dari ketakutan akan ancaman.

c. Sosial : kebutuhan akan cinta, perhatian, perasaan bersatu, dan kontak dengan manusia lainnya.

d. Pengakuan : kebutuhan dihormati orang lain, kebutuhan mampu menyelesaikan pekerjaan, dan kebutuhan self-esteem.

e. Aktualisasi : kebutuhan untuk berkembang, kebutuhan untuk mewujudkan potensi diri.

2. Teori Kebutuhan Berprestasi David McClelland

Menurut McClelland (dalam Hanafi, 2011) ada tiga kebutuhan dasar yang memotivasi manusia yaitu:

a. Kebutuhan akan kekuasaan (need for power atau n-pow) adalah manusia ingin mempunyai kekuasaan terhadap orang lain atau menginginkan posisi kepemimpinan.

b. Kebutuhan akan afiliasi (need for affiliation atau n-aff) yaitu manusia ingin berinteraksi dengan orang lain, mempunyai rasa cinta dan ingin menghindari penolakan oleh kelompoknya.

c. Kebutuhan akan prestasi (need for achievement atau n-ach) yaitu manusia ingin berprestasi sekaligus kekhawatiran yang besar terhadap kegagalan.

3. Teori Existence, Relatedness, Growth (ERG) dari Alderfer (dalam Hanafi, 2011).

Teori ERG merupakan refleksi dari nama tiga dasar kebutuhan yaitu:

a. Kebutuhan eksistensi (existence needs) adalah kebutuhan ini berhubungan dengan kebutuhan fisiologis seperti makan, minum, pakaian, gaji, kondisi kerja.

b. Kebutuhan interaksi (relatedness needs) adalah kebutuhan yang berhubungan dengan orang lain, keluarga, atasan, bawahan, teman atau bahkan musuh.

c. Kebutuhan pertumbuhan (growth needs) adalah kebutuhan yang mendorong seseorang untuk lebih kreatif dan lebih produktif.

Dengan memahami berbagai teori motivasi diatas, seorang pemimpin dapat mengetahui kebutuhan karyawannya. Dengan mengetahui kebutuhan karyawan, pimpinan dapat memenuhi apa yang dibutuhkan karyawan, sehingga karyawan dapat lebih termotivasi dalam bekerja. Apabila motivasi kerja karyawan meningkat maka kinerjanya juga akan meningkat. Peningkatan kinerja karyawan merupakan satu hal yang sangat diharapkan oleh perusahaan. Oleh karena kinerja perusahaan sangat tergantung pada kinerja individu karyawan maka perusahaan harus menghargai perbedaan kinerja yang dihasilkan setiap karyawan. Salah satu bentuk penghargaan kinerja bagi karyawan adalah pemberian insentif. Karyawan yang berkinerja tinggi akan mendapatkan insentif besar, sedangkan untuk yang berkinerja lebih rendah tentu saja mendapatkan insentif yang lebih kecil. 


\section{Insentif}

Menurut Rivai (2009) insentif diartikan sebagai bentuk pembayaran langsung yang dikaitkan langsung dengan kinerja dan gain sharing, yang juga dikaitkan dengan kinerja dan diartikan sebagai pembagian keuntungan bagi karyawan akibat peningkatan produktivitas atau penghematan biaya. Tujuan utama dari insentif adalah untuk memberikan tanggung jawab dan dorongan kepada karyawan dalam rangka meningkatkan kualitas dan kuantitas hasil kerjanya. Sedangkan bagi perusahaan, insentif merupakan strategi untuk meningkatkan produktivitas dan efisiensi perusahaan dalam menghadapi persaingan yang semakin ketat karena produktivitas menjadi satu hal yang sangat penting.

Sistem pemberian insentif merupakan bentuk pemberian bonus atau insentif yang dilakukan perusahaan berdasarkan kinerja bisnis perusahaan dan kinerja perorangan. Sistem insentif ada pada hampir setiap jenis pekerjaan dari tenaga kerja manual sampai professional, manajer, dan pekerja eksekutif. Sistem pemberian insentif terdiri dari bonus tahunan, insentif langsung, insentif individu, insentif tim, pembagian keuntungan, dan bagi hasil.

Adanya insentif bagi seorang karyawan yang bekerja diperusahaan, karyawan akan merasa bahwa pekerjaan yang dilakukannya dinilai dan dihargai oleh perusahaan, sehingga setelah karyawan mendapatkan insentif maka karyawan tersebut akan merasakan puas dalam bekerja. Apabila insentif yang diberikan perusahaan sesuai dengan harapan, tentunya karyawan tersebut mendapatkan kepuasan tersendiri dalam bekerja.

\section{Kepuasan Kerja}

Menurut Rivai (2009) kepuasan kerja pada dasarnya merupakan sesuatu yang bersifat individual. Setiap individu memiliki tingkat kepuasan yang berbeda-beda sesuai dengan sistem nilai yang berlaku pada dirinya. Semakin tinggi penilaian terhadap kegiatan dirasakan sesuai dengan keinginan individu, semakin tinggi kepuasannya terhadap kegiatan tersebut. Faktor-faktor yang dapat memengaruhi kepuasan kerja karyawan pada dasarnya secara praktis dapat dibedakan menjadi dua kelompok, yaitu:

1. Faktor intrinsik adalah faktor yang berasal dari dalam diri dan dibawa oleh setiap karyawan sejak mulai bekerja di tempat pekerjaannya.

2. Faktor ekstrinsik adalah menyangkut hal-hal yang berasal dari luar diri karyawan, antara lain kondisi fisik lingkungan kerja, instriksiknya dengan karyawan lain, sistem penggajian, dan sebagainya.

Indikator Kepuasan kerja menurut Rivai (2009) adalah sebagai berikut:

a. Prestasi

b. Pekerjaan

c. Pertumbuhan dan perkembangan diri

d. Kondisi kerja

e. Kualitas hubungan

f. Jaminan sosial

Kepuasan kerja yang diperoleh antar individu bisa saja berbeda. Oleh karena itu, bagi seorang karyawan yang bekerja merasa puas dengan apa yang telah dikerjakan tentunya dapat berdampak pada kinerja, biasanya kepuasan tersebut dapat meningkatkan kinerja karyawan.

\section{Kinerja}

Menurut Bacal (2012) dalam Wibowo (2017) manajemen kinerja adalah proses komunikasi yang sedang berjalan, dilakukan dengan kemitraan antara pekerja dengan atasan langsung mereka yang menyangkut menciptakan harapan yang jelas dan saling pengertian tentang pekerjaan yang harus dilakukan. Prinsip dasar manajemen kinerja menjadi fondasi yang kuat bagi kinerja organisasi untuk mencapai tujuan. Menurut Wibowo (2017) kinerja adalah tentang melakukan pekerjaan dan hasil yang dicapai dari pekerjaan tersebut. Kinerja adalah tentang apa yang dikerjakan dan bagaimana cara mengerjakan. Faktor-faktor yang memengaruhi kinerja menurut Armstrong dan Baron dalam Wibowo (2017) yaitu:

1. Personal factor, ditunjukkan oleh tingkat ketrampilan, kompetensi yang dimiliki, motivasi, dan, komitmen individu. 
2. Leadership factor, ditentukan oleh kualitas dorongan, bimbingan, dan dukungan yang dilakukan manajer dan team leader.

3. Team factor, ditunjukkan oleh kualitas dukungan yang diberikan oleh rekan sekerja.

4. System factor, ditunjukkan oleh adanya sistem kerja dan fasilitas yang diberikan organisasi.

5. Contextual/situational factor, ditunjukkan oleh tingginya tingkat tekanan dan perubahan lingkungan internal dan eksternal.

\section{Pengembangan Hipotesis}

\section{Hubungan motivasi dengan kinerja karyawan}

Hampir semua teori motivasi mengacu pada teori kebutuhan manusia, termasuk teori motivasi dari Abraham Maslow. Pada dasarnya setiap manusia melakukan sesuatu karena adanya kebutuhan yang ingin dipenuhinya. Abraham Maslow mengemukakan hirarkis lima kebutuhan manusia yaitu 1) kebutuhan sandang, pangan, dan papan (fisiologis), 2) kebutuhan akan keamanan dan bebas dari ketakutan akan ancaman, 3) kebutuhan akan cinta, perhatian, perasaan bersatu, dan kontak dengan manusia lainnya (kebutuhan sosial), 4) kebutuhan dihormati orang lain, kebutuhan mampu menyelesaikan pekerjaan, dan kebutuhan self-esteem (pengakuan), dan 5) kebutuhan untuk berkembang dan mewujudkan potensi diri (aktualisasi diri). Manusia bekerja untuk memenuhi semua kebutuhan tersebut. Apabila perusahaan tempat kerjanya dapat memenuhi semua kebutuhan hidupnya, tentu saja seseorang akan termotivasi untuk bekerja lebih baik lagi, sehingga kinerjanya dapat meningkat. Semakin tinggi motivasi kerja seseorang maka akan semakin tinggi juga kinerjanya.

Pendapat tersebut terbukti dalam penelitian yang dilakukan oleh Nugroho, dkk (2017) dengan subjek pegawai Dinas Pertanian Kota Semarang bahwa motivasi berpengaruh positif dan signifikan terhadap kinerja pegawai. Temuan yang sama diperoleh dari penelitian Setiyaningsih (2018) dengan responden Driver Go-Car PT Gojek Indonesia Wilayah Yogyakarta. Berdasarkan hal tersebut maka hipotesis yang dapat dipaparkan dalam penelitian ini adalah:

$\mathrm{H}_{1}$ : Motivasi berpengaruh positif terhadap kinerja driver Grab-Bike Kabupaten Banjarnegara.

\section{Hubungan insentif dengan kinerja karyawan}

Sistem pemberian insentif merupakan bentuk pemberian bonus atau insentif yang dilakukan perusahaan berdasarkan kinerja bisnis perusahaan dan kinerja perorangan. Sistem insentif ada pada hampir setiap jenis pekerjaan dari tenaga kerja manual sampai professional, manajer dan pekerja eksekutif. Jika organisasi mau mencapai insentif strategis mereka, pembayaran perlu dihubungkan dengan kinerja sedemikian rupa sehingga pembayaran itu mengikuti tujuan karyawan dan tujuan organisasi. Dengan demikian jelas bahwa insentif merupakan tambahan upah yang akan diterima karyawan apabila hasil kerjanya melebihi standar yang telah ditentukan perusahaan. Insentif menjadi pembeda antara karyawan yang berkinerja tinggi dan karyawan yang berkinerja rendah. Semakin tinggi insentif yang ditetapkan oleh perusahaan, diharapkan akan semakin tinggi kinerja karyawan.

Rompis, dkk (2017) telah membuktikan pernyataan tersebut dalam penelitian yang dilakukannya di PT Angkasa Pura 1 (Persero) Cabang Manado, bahwa insentif secara parsial berpengaruh signifikan terhadap kinerja karyawan. Berdasarkan hal tersebut maka hipotesis kedua yang dipaparkan dalam penelitian ini adalah:

$\mathrm{H}_{2}$ : Insentif berpengaruh positif terhadap kinerja driver Grab-Bike Kabupaten Banjarnegara.

\section{Hubungan kepuasan kerja dengan kinerja karyawan}

Kepuasan kerja sangat berperan dalam meningkatkan kinerja karyawan. Karyawan akan loyal dan merasa ingin terus menetap di perusahaan karena merasa puas melakukan pekerjaan pada tempat kerjanya. Penelitian Changgriawan (2017) telah membuktikan pernyataan tersebut. Dengan mengambil responden Karyawan One Way Production diperoleh hasil bahwa kepuasan kerja berpengaruh signifikan terhadap kinerja karyawan. Dengan demikian hipotesis ketiga yang dikemukakan dalam penelitian ini seperti berikut:

$\mathrm{H}_{3}$ : Kepuasan kerja berpengaruh positif terhadap kinerja driver Grab-Bike Kabupaten Banjarnegara. 
Hubungan motivasi, insentif, dan kepuasan kerja terhadap kinerja karyawan

Kinerja karyawan diantaranya dipengaruhi oleh personal factor dan system factor. Personal factor merupakan faktor yang ada dalam diri individu karyawan, seperti motivasi kerja karyawan dan kepuasan karyawan pada pekerjaan atau tempat kerjanya. System factor ditunjukkan oleh adanya sistem kerja dan fasilitas yang diberikan organisasi, termasuk sistem insentif yang diterapkan dalam suatu perusahaan. Dengan demikian, kinerja karyawan diantaranya dipengaruhi oleh motivasi, kepuasan kerja, dan insentif. Oleh karena secara parsial, masing-masing faktor tersebut telah dihipotesiskan mempengaruhi kinerja karyawan maka hipotesis keempat dirumuskan seperti berikut:

$\mathrm{H}_{4}$ : Motivasi, insentif, dan kepuasan kerja secara simultan berpengaruh positif terhadap kinerja driver Grab-Bike Kabupaten Banjarnegara.

Berikut adalah kerangka pemikiran yang diajukan dalam penelitian ini:

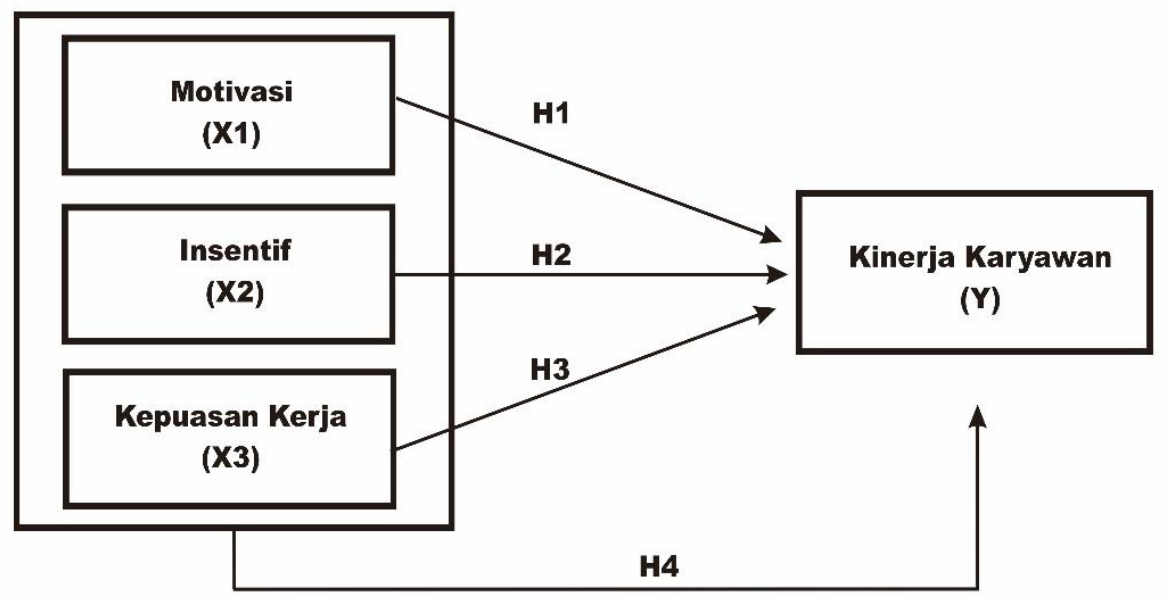

\section{METODE PENELITIAN}

\section{Definisi Operasional}

1. Variabel bebas (Independent Variable)

Menurut Wiyono (2011), variabel independen adalah variabel yang mempengaruhi atau menjadi sebab terjadinya perubahan terhadap variabel dependen. Dalam penelitian ini yang termasuk variabel bebas yang disimbolkan dengan huruf $\mathrm{X}$, adalah sebagai berikut:

a. Motivasi (X1)

Menurut teori Maslow dalam Hanafi (2011), motivasi dapat diukur dengan indikator sebagai berikut:

1) Fisiologis

2) Keamanan

3) Sosial

4) Pengakuan

5) Aktualisasi

b. Insentif (X2)

Menurut Rivai (2009), insentif dapat diukur dengan indikator sebagai berikut:

1) Tambahan upah/bonus

2) Komisi

3) Insentif non materi

4) Meritpay

c. Kepuasan Kerja (X3)

Menurut Rivai (2009), kepuasan kerja dapat diukur dengan indikator sebagai berikut:

1) Prestasi

2) Pekerjaan 
3) Pertumbuhan dan perkembangan diri

4) Kondisi kerja

5) Kualitas hubungan

6) Jaminan sosial

2. Variabel Terikat (Dependent Variable)

Menurut Wiyono (2011), variabel dependen adalah variabel yang dipengaruhi oleh variabel independen, sering juga disebut sebagai variabel terikat. Dalam penelitian ini, variabel dependennya adalah kinerja karyawan. Menurut Wibowo (2017), kinerja diukur dengan indicator :
a. Tujuan
b. Standar
c. Umpan balik
d. Kompetensi
e. Peluang

\section{Metode Pengambilan Sampel}

Populasi dalam penelitian ini adalah semua driver grab-bike pada Grab Indonesia Wilayah Kabupaten Banjarnegara. Oleh karena peneliti tidak mendapatkan jumlah driver yang pasti, maka digunakanlah sampel dalam penelitian ini. Pengambilan sampel dilakukan dengan menggunakan non probability sampling. Adapun metode yang digunakan adalah Metode Purposive Sampling. Menurut Wiyono (2011), Purposive Sampling artinya sebelum sampel diambil, ditentukan dulu batasan-batasan sampel seperti apa yang akan diambil. Pada penelitian ini sampel yang akan diambil adalah driver grab-bike Grab Indonesia Wilayah Kabupaten Banjarnegara yang telah mempunyai masa kerja minimal 6 bulan dengan alasan bila kurang dari 6 bulan dimungkinkan profesi driver di Grab hanya untuk kerja sampingan sehingga sulit untuk mengukur kinerjanya.

Banyaknya sampel yang diambil didasarkan pada rumus Hair et al. (1998) dalam buku Multivariate Data Analysis yang dikutip Husein Umar (2008) dalam Wiyono (2011) yang menyatakan bahwa jumlah sampel dapat ditentukan dengan mengalikan 5x jumlah item pertanyaan. Oleh karena kuesioner dalam penelitian ini memiliki 40 item pernyataan maka sampel yang digunakan minimal sebanyak 200 responden.

\section{Metode Pengambilan Data}

Data diambil dengan menggunakan kuesioner dengan skala Likert. Pengukuran setiap instrumen pernyataan menggunakan skala likert dari sangat setuju (skor nilai 5) sampai dengan sangat tidak setuju (skor nilai 1).

\section{Metode Analisis}

Metode analisis dalam penelitian ini meliputi uji instrumen (validitas dan reliabilitas), uji asumsi dasar (normalitas), uji asumsi klasik (multikolinearitas dan heteroskedastisitas), dan uji hipotesis. Untuk mengetahui arah hubungan antara variabel independen dan dependen, digunakan uji regresi linier berganda. Adapun persamaannya adalah sebagai berikut:

$\mathrm{Y}=\alpha+\mathrm{b} 1 \mathrm{X} 1+\mathrm{b} 2 \mathrm{X} 2+\mathrm{b} 3 \mathrm{X} 3+\mathrm{e}$

Keterangan :

$\mathrm{Y} \quad=$ Kinerja

$\alpha=$ konstanta

b1 = Koefisien motivasi

$\mathrm{X} 1=$ Motivasi

b2 $=$ Koefisien insentif

$\mathrm{X} 2=$ Insentif

b3 = Koefisien kepuasan kerja

$\mathrm{X} 3=$ Kepuasan kerja

e $\quad=$ error term / standar error

Untuk mengetahui ada tidaknya pengaruh variabel independen dan dependen secara parsial digunakan uji t dengan $\alpha=0.05$. Sedangkan untuk mengetahui ada tidaknya pengaruh variabel independen dan dependen secara simultan digunakan uji F. Koefisien determinasi $\left(\mathrm{R}^{2}\right)$ digunakan untuk 
mengukur seberapa jauh kemampuan model dalam menerangkan variasi variabel dependen. Nilai koefisien determinasi adalah antara nol dan satu. Jika nilai $\mathrm{R}^{2}$ kecil berarti kemampuan variabelvariabel independen dalam menjelaskan variasi variabel dependen amat terbatas, sedangkan jika nilai $\mathrm{R}^{2}$ mendekati satu berarti variabel-variabel independen memberikan hampir semua informasi yang dibutuhkan untuk memprediksi variasi variabel dependen.

\section{HASIL DAN PEMBAHASAN}

Untuk kepentingan pengumpulan data, peneliti mendistribusikan 230 kuesioner. Namun demikian, kuesioner yang dapat digunakan hanya sejumlah 200 saja, karena pengisian tidak lengkap. Responden sejumlah tersebut sudah memenuhi persyaratan penelitian, seperti pendapat Hair et al. yang dikutip oleh Husein Umar (2008) dalam Wiyono (2011), bahwa jumlah sampel dapat ditentukan dengan $5 x$ jumlah item pertanyaan, yaitu $s=5 \times 40=200$ responden. Penelitian ini merupakan penelitian yang menggunakan data primer, yaitu data yang diperoleh dari penyebaran kuesioner. Pengolahan data dalam penelitian ini menggunakan SPSS 22.0 for Windows. Hasil uji instrumen, uji asumsi dasar, dan uji asumsi klasik menunjukkan bahwa semua instrumen dan semua variabel layak untuk digunakan dalam penelitian ini.

\section{Uji Regresi Linier Berganda}

Analisis regresi linier berganda ini dilakukan karena jumlah variabel independen yang digunakan dalam penelitian ini adalah 3 variabel, yaitu variabel motivasi, insentif, dan kepuasan kerja. Berdasarkan tabel 1 dapat dibentuk persamaan sebagai berikut:

$$
\mathrm{Y}=11,406+0,404 \mathrm{X} 1-0,008 \mathrm{X} 2+0,233 \mathrm{X} 3+\mathrm{e}
$$

Tabel 1

\section{Hasil Uji Regresi Linier Berganda}

\begin{tabular}{|c|c|c|c|c|c|}
\hline \multirow[b]{3}{*}{ Model } & \multicolumn{3}{|c|}{ Coefficients $^{a}$} & \multirow[b]{3}{*}{$\mathrm{t}$} & \multirow[b]{3}{*}{ Sig. } \\
\hline & \multicolumn{2}{|c|}{ Unstandardized Coefficients } & \multirow{2}{*}{$\begin{array}{c}\text { Standardized } \\
\text { Coefficients } \\
\text { Beta }\end{array}$} & & \\
\hline & $\mathrm{B}$ & Std. Error & & & \\
\hline (Constant) & 11.406 & 2.437 & & 4.681 & .000 \\
\hline Motivasi & .404 & .067 & .425 & 5.994 & .000 \\
\hline Insentif & -.008 & .074 & -.007 & -.105 & .917 \\
\hline Kepuasankerja & .233 & .060 & .277 & 3.905 & .000 \\
\hline
\end{tabular}

a. Dependent Variable: Kinerja

berikut:

Berdasarkan persamaan analisis regresi linier berganda tersebut dapat dijelaskan sebagai

1. Konstanta sebesar 11.406 , artinya bila tanpa motivasi, insentif, dan kepuasan kerja, maka nilai kinerja driver Grab-Bike Kabupaten Banjarnegara sebesar 11.406 satuan.

2. Koefisien regresi variabel motivasi sebesar 0.404 artinya variabel motivasi berpengaruh positif terhadap kinerja driver Grab-Bike Kabupaten Banjarnegara, jika motivasi mengalami kenaikan 1 satuan dan variabel lainnya tetap, maka kinerja mengalami peningkatan sebesar 0.404 satuan.

3. Koefisien regresi variabel insentif sebesar -0.008 artinya variabel insentif berpengaruh negatif terhadap kinerja driver Grab-Bike Kabupaten Banjarnegara, jika insentif mengalami kenaikan 1 satuan dan variabel lainnya tetap, maka kinerja mengalami penurunan sebesar 0.008 satuan.

4. Koefisien regresi variabel kepuasan kerja sebesar 0.233 artinya variabel kepuasan kerja berpengaruh positif terhadap kinerja driver Grab-Bike Kabupaten Banjarnegara, jika kepuasan kerja mengalami kenaikan 1 satuan dan variabel lainnya tetap, maka kinerja mengalami peningkatan sebesar 0.233 satuan. 


\section{Uji t}

Menurut Wiyono (2011), uji t atau uji parsial digunakan untuk mengetahui setiap masing-masing variabel independen mempunyai pengaruh atau tidak terhadap variabel dependen dan selanjutnya dapat diketahui variabel independen yang dominan berpengaruh terhadap variabel dependen dengan $\alpha=0,05$.

Berdasarkan tabel 1 diketemukan bahwa:

1. Variabel motivasi memiliki nilai signifikansi sebesar 0.000 , lebih kecil dari nilai $\alpha$ yang digunakan dalam penelitian ini. Dengan demikian dapat dikatakan bahwa motivasi berpengaruh terhadap kinerja driver grab-bike Kabupaten Banjarnegara.

2. Variabel insentif memiliki nilai signifikansi sebesar 0.917 , lebih besar dari nilai $\alpha$ yang digunakan dalam penelitian ini. Dengan demikian dapat dikatakan bahwa insentif tidak berpengaruh terhadap kinerja driver grab-bike Kabupaten Banjarnegara.

3. Variabel kepuasan kerja memiliki nilai signifikansi sebesar 0.000 , lebih kecil dari nilai $\alpha$ yang digunakan dalam penelitian ini. Dengan demikian dapat dikatakan bahwa kepuasan kerja berpengaruh terhadap kinerja driver grab-bike Kabupaten Banjarnegara.

\section{Uji F}

Uji F atau uji serentak digunakan untuk melihat bagaimanakah pengaruh seluruh variabel bebas secara simultan atau bersama-sama terhadap variabel dependen (Wiyono, 2011). Hasil uji $\mathrm{F}$ dengan $\alpha=0.05$ dapat dilihat pada tabel 2 berikut ini:

\section{Tabel 2}

Hasil Uji F

ANOVA $^{\mathrm{a}}$

\begin{tabular}{lrrrrr}
\hline Model & Sum of Squares & df & Mean Square & F & \multicolumn{1}{c}{ Sig. } \\
\hline 1 Regression & 1463.270 & 3 & 487.757 & 41.609 & $.000^{\mathrm{b}}$ \\
\hline Residual & 2297.605 & 196 & 11.722 & & \\
\hline Total & 3760.875 & 199 & & & \\
\hline
\end{tabular}

a. Dependent Variable: Kinerja

b. Predictors: (Constant), Kepuasankerja, Insentif, Motivasi

Berdasarkan tabel 2, diperoleh nilai signifikansi sebesar 0.000 , lebih kecil dari nilai $\alpha$ yang digunakan dalam penelitian ini. Dengan demikian, dapat dikatakan bahwa motivasi, insentif, dan, kepuasan kerja secara simultan berpengaruh terhadap kinerja driver grab-bike Kabupaten Banjarnegara.

\section{Koefisien Determinasi}

Hasil uji koefisien determinasi dalam penelitian ini disajikan pada tabel 3 dibawah ini:

$$
\text { Tabel } 3
$$

Hasil Uji Koefisien Determinasi Model Summary

\begin{tabular}{llrrrr}
\hline Model & R & R Square & $\begin{array}{c}\text { Adjusted R } \\
\text { Square }\end{array}$ & $\begin{array}{c}\text { Std. Error of the } \\
\text { Estimate }\end{array}$ \\
\hline 1 & $.624^{\mathrm{a}}$ & .389 & .380 & 3.424 \\
\hline
\end{tabular}

a. Predictors: (Constant), Kepuasankerja, Insentif, Motivasi

Berdasarkan tabel 3 diatas, diperoleh nilai Adjusted R Square sebesar 0,380 (38\%). Hal ini berarti bahwa 38\% variabel kinerja driver grab-bike Kabupaten Banjarnegara dijelaskan oleh variabel motivasi, insentif, dan kepuasan kerja, sedangkan sisanya sebesar $62 \%$ dijelaskan oleh faktor lain yang tidak termasuk dalam penelitian ini.

\section{Pembahasan}

Dari semua uji yang telah dianalisis menggunakan SPSS 22.0 for Windows, bahwa tidak semua hipotesis dapat diterima. Hipotesis pertama yang menyatakan bahwa motivasi berpengaruh positif terhadap kinerja driver Grab-Bike Kabupaten Banjarnegara, diterima. Temuan ini sangatlah 
masuk akal karena driver bekerja untuk memenuhi kebutuhan hidupnya. Kebutuhan hidup manusia tertuang dalam Teori Maslow yang digunakan sebagai indikator untuk mengukur variabel motivasi dalam penelitian ini. Dengan demikian jelas bahwa semakin tinggi motivasi driver dalam bekerja maka semakin tinggi kinerjanya. Temuan ini sejalan dengan penelitian yang dilakukan oleh Nugroho, dkk (2017) di Dinas Pertanian Kota Semarang dan penelitian Setiyaningsih (2018) dengan subyek driver Go-Car PT Gojek Indonesia Wilayah Yogyakarta. Studi Kasus pada Karyawan PT BPR Kertha Arthamandiri Kepanjen Malang yang dilakukan oleh Prihantini, dkk (2017) dan riset di One Way Production yang dilakukan oleh Changgriawan (2017) menghasilkan temuan berbeda, bahwa motivasi kerja tidak berpengaruh terhadap kinerja karyawan.

Hipotesis kedua yang menyatakan bahwa insentif berpengaruh positif terhadap kinerja driver Grab-Bike Kabupaten Banjarnegara, ditolak. Hal tersebut dapat terjadi karena pada saat peneliti mendistribusikan kuesioner, driver grab-bike berkeluh kesah tentang insentif/bonus driver grab-bike di wilayah Kabupaten Banjarnegara yang mengalami penurunan. Selain dikarenakan tarif bonus yang mengalami penurunan, cara pembayaran bonus yang tidak secara langsung itu juga menjadi keluhan tersendiri bagi para driver. Bonus diterima di rekening driver seminggu sekali, yaitu setiap hari Jum'at saja. Dengan demikian driver grab-bike bekerja kurang maksimal dan tidak sesuai dengan targetnya yang membuat kinerjanya mengalami penurunan. Temuan ini samadengan hasil penelitian yang dilakukan oleh Nugroho, dkk (2017) di Dinas Pertanian Kota Semarang, bahwa pemberian insentif tidak berpengaruh positif dan signifikan terhadap kinerja pegawai. Temuan ini berbeda dengan hasil riset Rompis, dkk (2017) di PT Angkasa Pura 1 (Persero) Cabang Manado.

Hipotesis ketiga diterima yang menyatakan bahwa kepuasan kerja berpengaruh positif terhadap kinerja driver Grab-Bike Kabupaten Banjarnegara. Indikator kepuasan kerja yang digunakan dalam penelitian ini ternyata berpengaruh positif terhadap kinerja driver, artinya semakin tinggi kepuasan kerjanya maka kinerjanya juga semakin tinggi. Temuan ini sejalan dengan hasil penelitian yang dilakukan oleh Changgriawan (2017) di One Way Production, namun berbeda dengan temuan Hidayati dan Rahmawati (2015) yang mengambil subjek karyawan Layanan Kesehatan Puskesmas di Kalimantan Timur.

Secara bersama-sama, ketiga variabel independen dalam penelitian ini berpengaruh terhadap kinerja driver $\left(\mathrm{H}_{4}\right.$ diterima) walaupun hanya sebesar $38 \%$ saja. Dengan demikian dapat dikatakan bahwa kinerja driver Grab-Bike Kabupaten Banjarnegara tidak begitu dipengaruhi oleh variabel motivasi, insentif/bonus, dan kepuasan kerja. Masih ada variabel-variabel lain yang memiliki pengaruh lebih besar terhadap kinerja driver Grab-Bike Kabupaten Banjarnegara.

\section{PENUTUP}

Kesimpulan

Berdasarkan analisis dan pembahasan yang telah dilakukan maka dapat diperoleh kesimpulan sebagai berikut:

1. Motivasi berpengaruh positif dan signifikan terhadap kinerja driver grab-bike Kabupaten Banjarnegara, hal ini ditunjukkan dengan koefisien regresi motivasi sebesar 0.404 dengan nilai signifikansi 0.000 . Dengan demikian $\mathrm{H}_{1}$ diterima.

2. Insentif berpengaruh negatif dan tidak signifikan terhadap kinerja driver grab-bike Kabupaten Banjarnegara, hal ini ditunjukkan dengan koefisien regresi insentif sebesar -0.008 dengan nilai signifikansi 0.917 . Dengan demikian $\mathrm{H}_{2}$ ditolak.

3. Kepuasan kerja berpengaruh positif dan signifikan terhadap kinerja driver grab-bike Kabupaten Banjarnegara, hal ini ditunjukkan dengan koefisien regresi kepuasan kerja sebesar 0.233 dengan nilai signifikansi 0,000. Dengan demikian $\mathrm{H}_{3}$ diterima.

4. Motivasi, insentif, dan kepuasan kerja secara simultan berpengaruh positif dan signifikan terhadap kinerja driver grab-bike Kabupaten Banjarnegara, hal ini ditunjukkan dengan hasil uji $\mathrm{F}$ pada tabel $\mathrm{ANOVA}^{\mathrm{a}}$ dengan nilai signifikansi 0,000. Dengan demikian $\mathrm{H}_{4}$ diterima.

\section{Saran}

Dari hasil analisis dan kesimpulan yang telah diuraikan, maka saran-saran yang dapat diberikan sebagai berikut: 
1. Perusahaan Grab Indonesia hendaknya lebih memperhatikan sistem pemberian insentif/bonus yang diberikan kepada para driver Grab-Bikenya, baik dari sisi jumlah maupun waktu pemberiannya. Dengan demikian tujuan pemberian insentif untuk peningkatan kinerja karyawan dapat tercapai.

2. Perusahaan Grab Indonesia hendaknya melakukan pembaruan aplikasinya secara terusmenurus agar para driver dapat bekerja dengan target mereka serta mendapatkan kepuasan dalam bekerja. Kepuasan kerja yang diperoleh antar driver berbeda, karena jika mereka beruntung langsung mendapatkan orderan yang sesuai (resto masih berdiri dan harga sesuai di aplikasi). Apabila dari mereka yang kurang beruntung, yaitu mendapat orderan food dengan harga yang dulu atau belum di update, kemudian pembayarannya menggunakan $O V O$ (grab-pay), karena harga yang ada di dalam aplikasi lebih murah dibandingkan harga yang sebenarnya disebabkan mengalami kenaikan. Dengan demikian para driver harus 'nombok'.

3. Untuk penelitian berikutnya hendaknya menambah variabel independen lainnya yang diduga memengaruhi kinerja driver, seperti kondisi demografis dan geografis masyarakat. Hal ini didasarkan pada temuan bahwa motivasi, insentif, dan kepuasan kerja secara simultan hanya mempengaruhi kinerja driver grab-bike Kabupaten Banjarnegara sebesar 38\% saja. Dengan demikian masih ada banyak variabel yang diduga mempengaruhi kinerja driver Grab-Bike.

\section{DAFTAR PUSTAKA}

Changgriawan, Garry Surya. 2017. Pengaruh Kepuasan Kerja dan Motivasi Kerja terhadap Kinerja Karyawan di One Way Production, Jurnal AGORA Universitas Kristen Petra.Surabaya. Volume 5. Nomor 3.

Dessler, Gary. 2015. Manajemen Sumber Daya Manusia. (alih bahasa: Diana Angelica). Edisi ke 14. Jilid 1. Jakarta: Salemba Empat.

Ghozali, Imam. 2018. Aplikasi Analisis Multivariate dengan program IBM SPSS 25, UNDIP. Semarang

Hanafi, Mahmud M.. 2011. Manajemen Edisi Ketiga, Yogyakarta: UPP STIM YKPN.

Hidayati dan Rahmawati. 2015. Pengaruh Kepuasan Kerja terhadap Komitmen Organisasi dan Kinerja Pegawai serta Kinerja Layanan studi pada Layanan Kesehatan Puskesmas di Kalimantan Timur, Jurnal MADIC. Universitas Pancasila Jakarta.

Nugroho, Haryono, dan Hasiolan. 2017. Pengaruh Pelatihan Kerja, Motivasi, dan Pemberian Insentif terhadap Kinerja Pegawai Dinas Pertanian Kota Semarang, Jurnal. Universitas Pandanaran Semarang.

Prihantini, Mansur, dan Khoirul. 2017. Pengaruh Kompensasi, Motivasi, dan Disiplin Kerja terhadap Kinerja Karyawan (Studi Kasus pada Karyawan PT. BPR Kertha Arthamandiri Kepanjen, Malang), Jurnal. UNISMA.Malang

Rivai, Veitzhal. 2009. Islamic Human Capital dari teori ke praktik Manajemen Sumber Daya Islami, Jakarta: PT RajaGrafindo Persada.

Rompis, Tumbel, dan Sendow. 2017. Pengaruh Kualitas Kehidupan Kerja, Kompetensi, dan Insentif terhadap Kinerja Karyawan PT Angkasa Pura 1 (Persero) Cabang Manado, Jurnal EMBA. Universitas Sam Ratulangi Manado.

Setiyaningsih, Dwi. 2018. Pengaruh Motivasi, Kompensasi, dan Lingkungan Kerja terhadap Kinerja Driver Go-Car PT Gojek Indonesia Wilayah Yogyakarta. Skripsi. STIM YKPN.

Wibowo. 2017. Manajemen Kinerja Edisi Kelima, Depok: PT RajaGrafindo Persada. 
Jurnal Manajemen dan Bisnis MEDIA EKONOMI, Vol . XIX No 1 Januari 2019

Wiyono, Gendro. 2011. Merancang Penelitian Bisnis dengan Alat Aplikasi SPSS 17.0 \& SmartPLS 2.0, Yogyakarta: UPP STIM YKPN.

Pustaka online:

https://www.grab.com/

(Diakses tanggal 7 November 2018)

https://economy.okezone.com/

(Diakses tanggal 8 November 2018) 